\title{
Impact of an exotic clam, Corbula gibba, on the commercial scallop Pecten fumatus in Port Phillip Bay, south-east Australia: evidence of resource- restricted growth in a subtidal environment
}

\author{
Sonia G. Talman ${ }^{1,2, *}$, Michael J. Keough ${ }^{2}$ \\ ${ }^{1}$ Marine and Freshwater Resources Institute, PO Box 114, Queenscliff, Victoria 3225, Australia \\ ${ }^{2}$ Department of Zoology, University of Melbourne, Victoria 3010, Australia
}

\begin{abstract}
Corbula gibba (Olivi, 1792) a small exotic bivalve from the eastern Atlantic and the Mediterranean has been present in Port Phillip Bay, Victoria, Australia, from as early as 1987. C. gibba is widespread, abundant, and possesses characteristics such as fast growth which may confer a competitive advantage over endemic species like the commercial scallop Pecten fumatus Reeve, 1855. Experimental manipulations in the field showed that ambient densities of C. gibba significantly affected the size and growth of juvenile $P$. fumatus. This effect was greater than the effect of an equivalent number of conspecific scallops. C. gibba did not, however, affect scallop condition or survival in the short term, although the power of the test to detect a $50 \%$ decrease in survival was low. The percentage of experimental scallops lost to different sources of mortality was also unaffected by the presence of C. gibba, as was the density of predators found in experimental enclosures. This study is the first to experimentally demonstrate the impact of an introduced marine mollusc on an endemic species in Australia. A possible mechanism underlying this impact is competition for food, as both species are suspension feeders which live in an environment where resource limitation may occur.
\end{abstract}

KEY WORDS: Bivalve molluscs · Exotic/introduced/non-indigenous species · Density manipulation · Resource limitation

Resale or republication not permitted without written consent of the publisher

\section{INTRODUCTION}

The introduction of non-indigenous aquatic species is a serious environmental problem globally. Accidentally or deliberately introduced species may threaten human health, fishing and aquaculture industries, and natural ecosystems of recipient environments (e.g. Nichols et al. 1990, Strayer et al. 1999). Bivalve molluscs include some particularly successful invaders of aquatic environments, as exemplified by the spread

*Present address: National Institute of Water and Atmospheric Research, PO Box 11-115, Hamilton, New Zealand.

E-mail: s.talman@niwa.cri.nz and explosive population growth of the zebra mussel Dreissena polymorpha, in the Great Lakes system of North America (Griffiths et al. 1991) and the invasion of San Francisco Bay by the Asian clam Potamocorbula amurensis (Carlton et al. 1990). These invasions are reported to have had major ecological and, in the case of D. polymorpha, economic impacts (Nichols et al. 1990, Strayer et al. 1999).

Corbula gibba (Olivi, 1792), a small bivalve mollusc native to the eastern Atlantic and the Mediterranean, was first identified in Port Phillip Bay, Australia, in 1991 (Currie \& Parry 1996) and subsequently identified in archived samples taken in 1987 (N. Coleman pers. comm.). Its occurrence in Port Phillip Bay is the first 
documented record of the species outside its area of natural distribution. Members of the family Corbulidae are cosmopolitan in distribution and occur in large numbers in their preferred habitat (Lamprell et al. 1998), characteristics that predispose them to successful establishment after introduction (e.g. Simberloff 1989).

Corbula gibba is now widespread and highly abundant in Port Phillip Bay (Talman 1998), so the natural ecosystem may be affected by its introduction. In some areas of the bay, C. gibba has been recorded in densities of $2600 \mathrm{~m}^{-2}$ (Currie \& Parry 1996), but it has the potential to reach densities of $53000 \mathrm{~m}^{-2}$ (Jensen 1990). C. gibba also possesses a number of characteristics that may give it a competitive advantage over endemic species, such as the capacity for fast growth (Jensen 1990) and the ability to tolerate a wide range of environmental conditions including partial anoxia (Christensen 1970), extreme eutrophication (Crema et al. 1991), and levels of turbidity that preclude other species (Bonvicini Pagliai et al. 1985).

Speculation on the impacts of exotic species is often based on long-term survey and observational data (Wilson et al. 1998, Currie \& Parry 1999). While such information is undoubtedly important, experimental manipulation and quantitative data are required to dis-
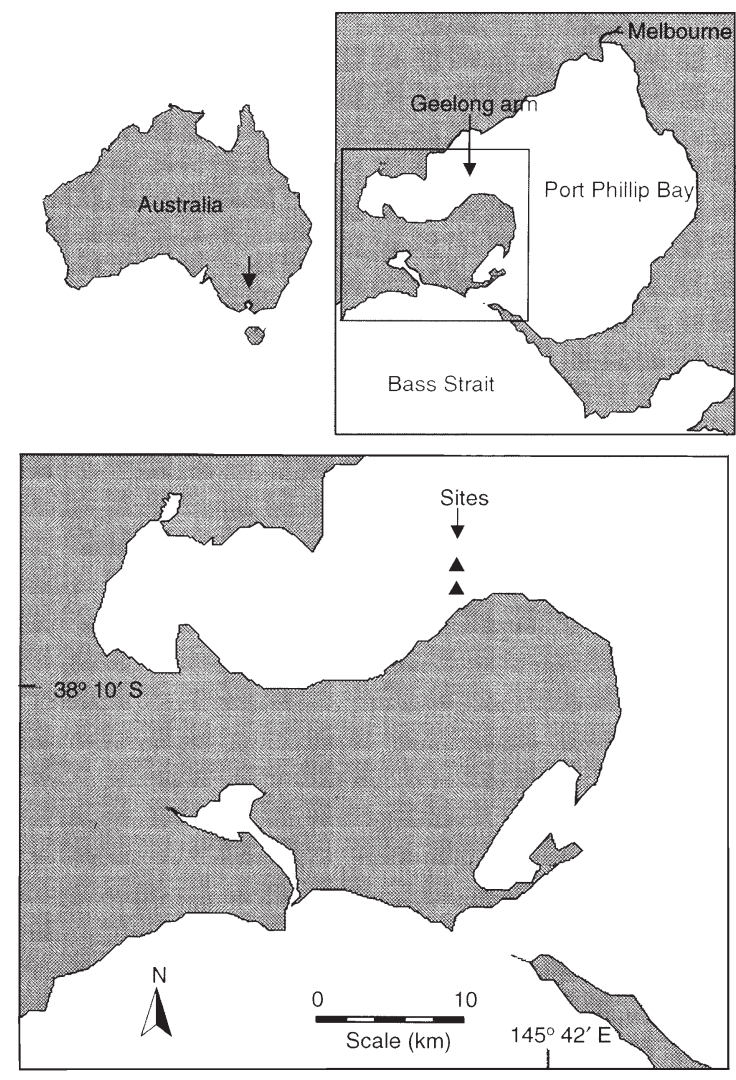

Fig. 1. Location of sites in Geelong arm of Port Phillip Bay, south-eastern Australia tinguish the impact of an invasion from natural variability. Despite the huge numbers of exotic species documented in marine environments worldwide, such experimental data are surprisingly scarce (Ruiz et al. 1999). Of the 196 exotic marine species recorded in Australia (C. Hewitt pers. comm.), experimental impact data exist only for the fanworm Sabella spallanzanii (Holloway 1999), the seastar Asterias amurensis (J. Ross unpubl. data) and the shore crab Carcinus maenas (Sinclair 1997). No such data exist for Corbula gibba.

Corbula gibba might affect endemic species via habitat modification, predation on planktonic larvae, and competition, and 1 species of concern is the commercial scallop Pecten fumatus Reeve, 1852. The fishery for this species closed in 1996, partly as a result of depleted stocks. C. gibba and P. fumatus overlap in distribution. A bay-wide survey conducted in 1998 showed that they co-occurred at 15 of the 28 sites sampled, in sandy-muddy sediments at depths of 7 to $22 \mathrm{~m}$ (Talman 1998, Cohen et al. 2000). Also, as suspension feeders, they presumably utilize similar food resources. C. gibba and P. fumatus may therefore compete for space and/or food, especially in the deeper regions of Port Phillip Bay where C. gibba is highly abundant (Talman 1998).

Our study aimed to (1) experimentally determine the impacts of Corbula gibba and conspecific scallops on the size, growth, condition, and survival of juvenile native scallops in the field, as well as to (2) assess the effects of C. gibba and conspecific scallops on factors of scallop mortality such as starvation and crab predation. The experiment was conducted at 2 sites in Port Phillip Bay to assess the generality of the results.

\section{MATERIALS AND METHODS}

Port Phillip Bay is a semi-enclosed, predominantly tidal embayment (surface area of $1.95 \times 10^{9} \mathrm{~m}^{2}$ ) that is linked to Bass Strait by a narrow entrance. The experiment was done at 2 sites within the Geelong arm of Port Phillip Bay, where scallops are known to occur. One site was located inshore, in $8 \mathrm{~m}$ of water, while the other was located further north, in $15 \mathrm{~m}$ of water (Fig. 1).

Pecten fumatus were obtained from Shellfish Culture Ltd., Tasmania, on 29 March 1999, and Corbula gibba were collected by divers in Port Phillip Bay during January 1999. All animals were held in laboratory aquaria with flow-through filtered $(30 \mu \mathrm{m})$ seawater and occasionally fed powdered algae until 30 March 1999.

Immature scallops were used in this experiment because they are more likely to interact with Corbula gibba than adults: they are similar in size (approx. 10 to 
$15 \mathrm{~mm}$ in length compared to 7 to $10 \mathrm{~mm}$ for C. gibba), use the same microhabitat, and, perhaps, similar food resources. Immature scallops are also fast-growing, with few energy reserves, so the effects of competition on size and growth would be detected more readily than for adults. Using reproductively immature scallops also avoided the confounding effect of gametogenesis on soft tissue weight (Martinez \& Mettifogo 1998)

Densities of both species were manipulated within experimental cages. Cages consisted of a steel frame $\left(330 \times 330 \mathrm{~mm}=0.1 \mathrm{~m}^{2}, 200 \mathrm{~mm}\right.$ height $)$ covered with steel mesh ( $5 \mathrm{~mm}$ square). The mesh on the top of the cage was removable. To a base density of 30 juvenile Pecten fumatus per $0.1 \mathrm{~m}^{2}$ (control), either 40 adult Corbula gibba (Treatment 1) or 40 extra juvenile scallops (Treatment 2) were added. This design allowed for the separation of intra- and interspecific effects on scallops, since Treatments 1 and 2 contained equal numbers of bivalves, although biomass was probably slightly greater in Treatment 2 because native scallops were initially larger than C. gibba individuals.

The density of Corbula gibba in Treatment 1 corresponded to local density, as determined from 20 random Eckman grab $\left(0.025 \mathrm{~m}^{2}\right)$ samples taken near the deeper site in February 1999. This density therefore dictated the density of extra scallops in Treatment 2. The base of Pecten fumatus was set at 30 individuals per $0.1 \mathrm{~m}^{2}$ to allow for a sufficient number of individuals to be recovered for analysis. This meant the density in Treatment 2 was 70 juvenile scallops per $0.1 \mathrm{~m}^{2}$. It is not known how this density relates to local densities of juvenile $P$. fumatus because such data are unavailable because of the cryptic nature of small scallops (Heasman et al. 1998) and their exclusion from stock-assessment surveys (Coleman 1998). However, according to data for juvenile $P$. maximus in Ireland, a density of 70 per $0.1 \mathrm{~m}^{2}$ is possible (although exceptional) in the wild (Minchin 1992).

At each of the 2 sites, 9 cages were deployed (3 replicates of each treatment) in a Latin-square design. Cages were separated from each other by $1 \mathrm{~m}$ and pushed into the sediment to a depth of approximately $50 \mathrm{~mm}$. The animals would not be in contact with the cage bottom at this depth because both species live close to the sediment-water interface (Yonge 1946, Coleman 1998). The use of cages and a large mesh size allowed the experimental bivalves to be exposed to the natural sediment and fauna of the site while preventing loss through emigration. The experiment commenced on 30 March 1999 and was recovered approximately 2 mo later, on 1 June 1999. Cages were cleared of accumulating algae and fouling organisms after 1 mo in the field to reduce the impact of these organisms on scallop growth.
Ten live scallops were randomly selected from each replicate at each site and 5 parameters were measured for each: shell area $\left(\mathrm{mm}^{2}\right)$, shell growth $\left(\mathrm{mm}^{2}\right)$, dry weight of shell and soft tissue, and ash-free dry weight of soft tissue (all weights in mg). To determine shell area, the surface area of the right valve was measured using BioScan Optimate 6.5 (Media Cybernetics, L.P., Silver Spring, MD), an image-analysis software package. To determine shell growth, the area of the shell at the time of deployment was measured and subtracted from the final shell area. It was possible to distinguish initial area because a single, highly visible disturbance ring was present on each shell. As these rings had not been present at the time of deployment, it was assumed that they represented the stress of relocation from the hatchery to the field. Such disturbance rings are readily formed on shells of young scallops (Minchin 1992). To determine shell and soft-body weights, the soft tissue was carefully removed from the shell and each component dried to a constant weight $\left(60^{\circ} \mathrm{C}\right.$ for $\left.48 \mathrm{~h}\right)$. The ash content of the soft tissue was then determined by burning off organic matter in a muffle furnace $\left(500^{\circ} \mathrm{C}\right.$ for $\left.7 \mathrm{~h}\right)$.

The condition index (ash-free dry soft tissue weight:dry shell weight) of these scallops was also determined (Lucas \& Beninger 1985). Low values indicate that energy reserves have been depleted, either for maintenance under poor environmental conditions or for gametogenesis (Martinez \& Mettifogo 1998). In this study, scallops were reproductively immature, so low index values would indicate an expenditure of energy for maintenance.

Animals in each cage were counted to obtain a value for percentage survival. The percentage of the original number of scallops that were lost to crabs (shells crushed and chipped), gastropods (shells with tubular boreholes), other agents such as starfish predation and starvation (shells undamaged) and unknown factors (shells missing) were determined. Potential predators found within each cage were identified and counted.

Comparisons of parameters were made with 2-factor (site and treatment) ANOVA. Cages were the unit for experimental replication, so mean values for individuals within each cage were used. If the effect of treatment was significant, planned comparisons were made between the control and each treatment. If the effect of treatment was non-significant, the power to detect a $50 \%$ decrease from the average control value was calculated. Before conducting an ANOVA, data were examined using boxplots to assess normality and homogeneity of variances. To satisfy these assumptions, it was necessary to $\log _{10}$-transform shell area, shell growth, dry weight of shell and soft tissue, and ashfree dry weight of soft tissue and to arcsine square-root transform percentage data. Condition index and predator density did not require transformation. 
Table 1. Pecten fumatus. Analysis of variance of body parameters $\left(\log _{10}\right.$-transformed). Bold-face values: $\mathrm{p}<0.05$

\begin{tabular}{|lrrrc|}
\hline Source of variation & df & Mean square & $F$ & $\mathrm{p}$ \\
\hline Shell area $\left(\mathrm{mm}^{2}\right)$ & & & & \\
$\quad$ Site & 1 & 0.031 & 6.853 & $\mathbf{0 . 0 2 2}$ \\
$\quad$ Treatment & 2 & 0.020 & 4.518 & $\mathbf{0 . 0 3 4}$ \\
Site $\times$ Treatment & 2 & 0.000 & 0.072 & 0.931 \\
$\quad$ Residual & 12 & 0.005 & & \\
Shell growth (mm $\left.{ }^{2}\right)$ & & & & \\
$\quad$ Site & 1 & 0.205 & 6.236 & $\mathbf{0 . 0 2 8}$ \\
Treatment & 2 & 0.142 & 4.327 & $\mathbf{0 . 0 3 8}$ \\
Site $\times$ Treatment & 2 & 0.002 & 0.068 & 0.935 \\
$\quad$ Residual & 12 & 0.033 & & \\
Shell dry wt (mg) & & & & \\
$\quad$ Site & 1 & 0.052 & 5.374 & $\mathbf{0 . 0 3 9}$ \\
Treatment & 2 & 0.046 & 4.714 & $\mathbf{0 . 0 3 1}$ \\
Site $\times$ Treatment & 2 & 0.001 & 0.092 & 0.913 \\
$\quad$ Residual & 12 & 0.010 & & \\
Soft tissue dry wt (mg) & & & & \\
$\quad$ Site & 1 & 0.072 & 5.651 & $\mathbf{0 . 0 3 5}$ \\
Treatment & 2 & 0.069 & 5.452 & $\mathbf{0 . 0 2 1}$ \\
Site $\times$ Treatment & 2 & 0.006 & $0 / 481$ & 0.630 \\
$\quad$ Residual & 12 & 0.013 & & \\
Soft tissue ash-free dry wt (mg) & & & \\
$\quad$ Site & 1 & 0.028 & 1.742 & 0.212 \\
Treatment & 2 & 0.064 & 3.974 & $\mathbf{0 . 0 4 7}$ \\
Site $\times$ Treatment & 2 & 0.000 & 0.006 & 0.994 \\
Residual & 12 & 0.016 & & \\
& & & & \\
\hline
\end{tabular}

Table 2. Pecten fumatus. Planned comparisons between treatments for body parameters ( $\log _{10}$-transformed). Bold-face values: $\mathrm{p}<0.05$

\begin{tabular}{|lc|}
\hline Source of variation & Comparison \\
\hline $\begin{array}{l}\text { Shell area }\left(\mathrm{mm}^{2}\right) \\
\text { Control vs Treatment } 1\end{array}$ & $F_{1,12}=8.900, \mathrm{p}=\mathbf{0 . 0 1 1}$ \\
$\quad$ Control vs Treatment 2 & $F_{1,12}=1.373, \mathrm{p}=0.264$ \\
Shell growth $\left(\mathrm{mm}^{2}\right)$ & \\
$\quad$ Control vs Treatment 1 & $F_{1,12}=8.629, \mathrm{p}=\mathbf{0 . 0 1 2}$ \\
$\quad$ Control vs Treatment 2 & $F_{1,12}=1.769, \mathrm{p}=0.208$ \\
Shell dry wt (mg) & \\
$\quad$ Control vs Treatment 1 & $F_{1,12}=9.418, \mathrm{p}=\mathbf{0 . 0 1 0}$ \\
$\quad$ Control vs Treatment 2 & $F_{1,12}=2.087, \mathrm{p}=0.174$ \\
Soft tissue dry wt (mg) & \\
$\quad$ Control vs Treatment 1 & $F_{1,12}=10.652, \mathrm{p}=\mathbf{0 . 0 0 7}$ \\
$\quad$ Control vs Treatment 2 & $F_{1,12}=4.274, \mathrm{p}=0.061$ \\
Soft tissue ash-free dry wt (mg) & \\
$\quad$ Control vs Treatment 1 & $F_{1,12}=7.905, \mathrm{p}=\mathbf{0 . 0 1 6}$ \\
Control vs Treatment 2 & $F_{1,12}=1.504, \mathrm{p}=0.244$ \\
\hline
\end{tabular}

\section{RESULTS}

Corbula gibba had a significant impact on the terminal size and growth of the shell, on the dry weight of shell and soft tissue, and on the ash-free dry weight of
Table 3. Pecten fumatus. Analysis of variance for condition index

\begin{tabular}{|lcccc|}
\hline Source of variation & df & Mean square & $F$ & $p$ \\
\hline Site & 1 & 0.000 & 0.904 & 0.360 \\
Treatment & 2 & 0.000 & 0.333 & 0.723 \\
Site $\times$ Treatment & 2 & 0.000 & 0.185 & 0.833 \\
Residual & 12 & 0.000 & & \\
& & & & \\
\hline
\end{tabular}

Table 4. Pecten fumatus. Analysis of variance of survival (\%) (arcsine square-root transformed)

\begin{tabular}{|lcccc|}
\hline Source of variation & df & Mean square & $F$ & $\mathrm{p}$ \\
\hline Site & 1 & 0.005 & 0.049 & 0.829 \\
Treatment & 2 & 0.050 & 0.480 & 0.630 \\
Site $\times$ Treatment & 2 & 0.087 & 0.828 & 0.460 \\
Residual & 12 & 0.105 & & \\
& & & & \\
\hline
\end{tabular}

soft tissue of juvenile Pecten fumatus (Table 1, Fig. 2). Compared to scallops in the control treatment, scallops in the presence of $C$. gibba had shells that were, on average, $35 \%$ lighter, $24 \%$ smaller, and exhibited $54 \%$ less growth (Table 2, Fig. 2). Similarly, individual soft tissue weight was, on average, $40 \%$ less than that obtained for control scallops (Table 2, Fig. 2). While C. gibba had a significant impact on the size and growth of scallops compared to controls, an equivalent number of extra scallops did not (Table 2, Fig. 2). The patterns were similar between sites, with no significant site-treatment interaction for any of the parameters measured (Table 1).

The condition of the scallops was variable and showed no significant relationship with either site or treatment (Table 3, Fig. 3). The power to detect a $50 \%$ decrease in condition index from the average value in the control treatment was $>0.99(\alpha=0.05)$. Scallop survival was also highly variable and did not differ between sites or treatments (Table 4, Fig. 3), although the power to detect a $50 \%$ decrease in survival from the average control value was low $(0.29, \alpha=0.05)$. The percentage of scallops lost to different sources of mortality did not differ between sites or treatments (Table 5). Approximately $40 \%$ of the scallops were lost to unknown factors, as the shells were missing from the cages (although this indicates predation of a sort that breaks up the shell), and another $10 \%$ were lost to agents of mortality that do not damage the shell, such as starfish predation, starvation and disease (Fig. 4). Crabs killed about $3 \%$ of the original number while no shells were found with the characteristic boreholes of predatory gastropods (Fig. 4). The only potential predators to be recovered from experimental cages were the crab species Litocheira bispinosa, Paguristes 

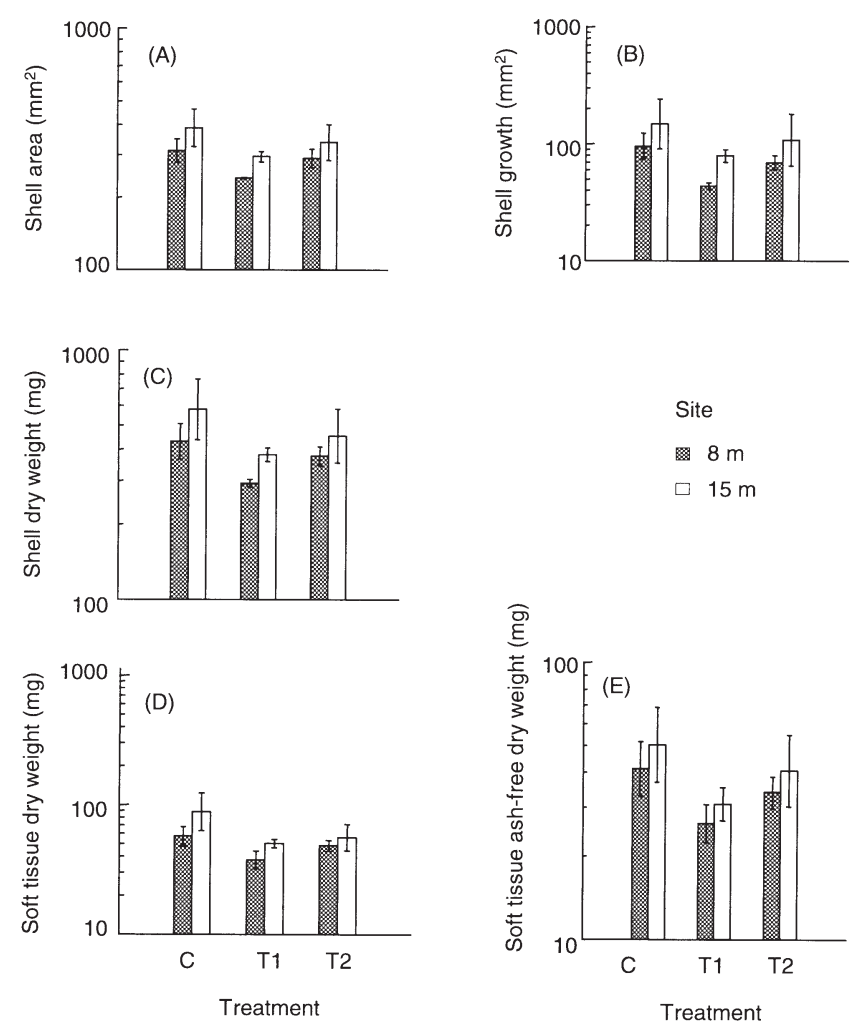

Fig. 2. Pecten fumatus. Area (A), growth (B) and dry wt (C) of juvenile shell and dry wt (D) and ash-free dry wt (E) of soft tissue (mean $\pm \mathrm{SE}$ ) amongst treatments and sites at conclusion of the experiment. C: control, 30 Pecten fumatus; T1: Treatment 1, 30 $P$. fumatus +40 Corbula gibba; T2: Treatment 2,70 P. fumatus. Note differences in scale

pugil, Ebalia (Phlyxia) intermedia and Pilumnopeus serratifrons, which were significantly more abundant at the shallow site (Table 6, Fig. 5).

The terminal size and growth of the shell and the dry weight of shell and soft tissue of juvenile Pecten fumatus were significantly greater at the $15 \mathrm{~m}$-deep site than at the $8 \mathrm{~m}$ deep site for all treatments (Table 1 , Fig. 2).

\section{DISCUSSION}

Ambient densities of Corbula gibba had a significant impact on the size and growth of the native juvenile Pecten fumatus at both sites. There is a general paucity of experimental tests of such impact worldwide (Ruiz et al. 1999), but particularly for introduced marine species in Australia. In terms of marine molluscs, experimental data only exist for species introduced into North America (e.g. Race 1982, Crooks 1998). While C. gibba had a significant impact on the size and growth of scallops compared to the controls, an equiv-
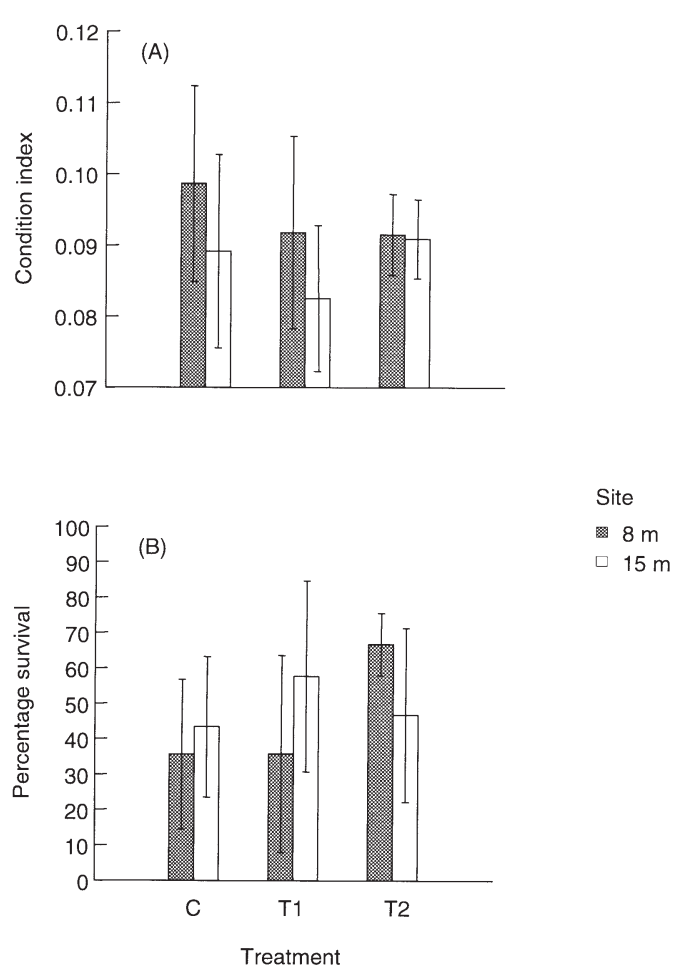

Fig. 3. Pecten fumatus. Condition and percentage survival of juveniles (mean $\pm \mathrm{SE}$ ) amongst treatments and sites at the conclusion of the experiment. Treatments as in Fig. 2. Percentage survival data were arcsine square-root transformed for analysis. Note differences in scale

alent number of additional scallops did not. This indicates that at the experimental density, which is rarely attained in the wild (Minchin 1992), juvenile Pecten fumatus do not compete with each other. Ólafsson

Table 5. Pecten fumatus. Analysis of variance for percentage lost to various sources of mortality (arcsine square-root transformed)

\begin{tabular}{|lrrcc|}
\hline Source of variation & df & Mean square & $F$ & $\mathrm{p}$ \\
\hline Crab predation & & & & \\
$\quad$ Site & 1 & 0.001 & 0.079 & 0.784 \\
$\quad$ Treatment & 2 & 0.004 & 0.231 & 0.797 \\
$\quad$ Site $\times$ Treatment & 2 & 0.020 & 1.217 & 0.330 \\
$\quad$ Residual & 12 & 0.016 & & \\
Other agents & & & & \\
$\quad$ Site & 1 & 0.007 & 0.175 & 0.684 \\
$\quad$ Treatment & 2 & 0.015 & 0.371 & 0.698 \\
$\quad$ Site $\times$ Treatment & 2 & 0.005 & 0.109 & 0.898 \\
$\quad$ Residual & 12 & 0.042 & & \\
Unknown factors & & & & \\
$\quad$ Site & 1 & 0.000 & 0.005 & 0.947 \\
$\quad$ Treatment & 2 & 0.079 & 0.940 & 0.417 \\
$\quad$ Site $\times$ Treatment & 2 & 0.045 & 0.543 & 0.595 \\
$\quad$ Residual & 12 & 0.084 & & \\
\hline
\end{tabular}




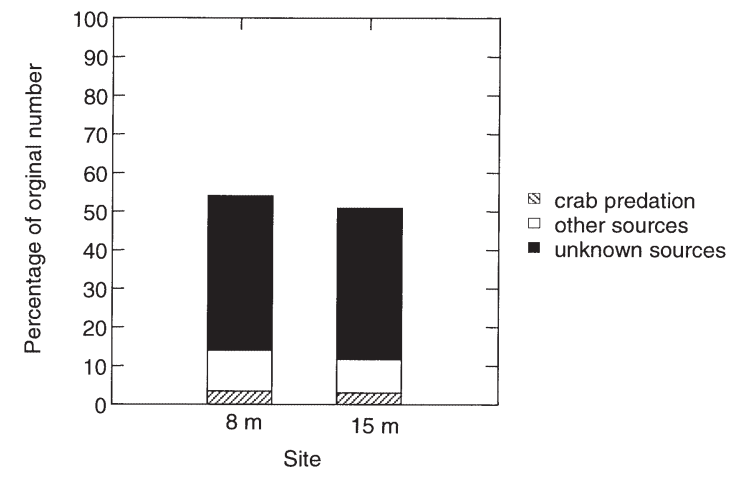

Fig. 4. Pecten fumatus. Mean percentage of original number of juveniles lost to crab predation (shells crushed and chipped), to other sources such as starfish predation and starvation (shells undamaged) or to unknown factors (shells missing) amongst sites. Data were arcsine square-root transformed for analysis

(1986) found that Macoma balthica was also unaffected by increased density, but other studies have demonstrated density-dependent growth for various bivalves (Broom 1982, Peterson 1982, Peterson \& Black 1987, 1988, Peterson \& Beal 1989), including P. fumatus, although this result was obtained at the artificially high densities used in aquaculture operations (Heasman et al. 1998). The greater importance of inter- versus intraspecific effects on the growth of juvenile Pecten fumatus contrasts with the results of Peterson (1982), who found that interspecific effects were usually non-significant and consistently far smaller than intraspecific effects.

The potential mechanisms underlying the impact of Corbula gibba on juvenile Pecten fumatus include competition for space and/or food. Space is unlikely to have been the limiting resource. Assuming C. gibba and $P$. fumatus to have the maximum sizes of 10 and

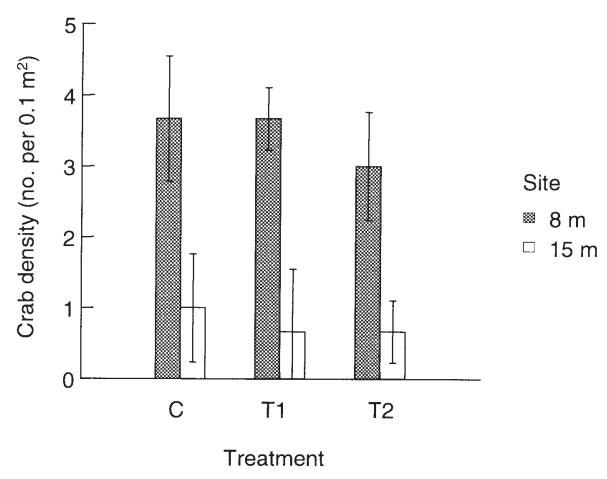

Fig. 5. Density (mean \pm SE) of crabs found in experimental cages amongst treatments and sites at the conclusion of the experiment. Treatments as in Fig. 2
Table 6. Analysis of variance of density (nos. per $0.1 \mathrm{~m}^{2}$ ) of crabs (various species) in experimental cages. Bold-face values: $\mathrm{p}<0.05$

\begin{tabular}{|lrrrr|}
\hline Source of variation & df & Mean square & \multicolumn{1}{c|}{$F$} & $\mathrm{p}$ \\
\hline Site & 1 & 32.000 & 36.000 & $\mathbf{0 . 0 0 0}$ \\
Treatment & 2 & 0.389 & 0.438 & 0.656 \\
Site $\times$ Treatment & 2 & 0.167 & 0.187 & 0.831 \\
Residual & 12 & 0.889 & & \\
& & & & \\
\hline
\end{tabular}

$15 \mathrm{~mm}$ respectively and to be square in shape, areal coverage by bivalves would have been approximately $10 \%$ in Treatment 1 and $14.5 \%$ in Treatment 2 . In addition, $P$. fumatus is essentially epibenthic while C. gibba is endobenthic, reducing actual crowding. Another possible mechanism is competition for food. The quality and quantity of available food is one of the primary factors controlling growth and fecundity in pectinids (e.g. MacDonald \& Thompson 1985, Pilditch $\&$ Grant 1999). Food limitation may therefore have a pronounced effect on size and growth. However, this mechanism can only account for the observed pattern if C. gibba and P. fumatus utilise some of the same food items and local food depletion by bivalves occurs. $C$. gibba and $P$. fumatus are suspension feeders that live and feed at the sediment surface and so, presumably, utilise similar food resources. Benthic food species are important for the scallop, Placopecten magellanicus (Shumway et al. 1987) and probably for $C$. gibba, as it ingests a large amount of sediment during feeding (Yonge 1946). However, data on the actual size and character of particles consumed by C. gibba and $P$. fumatus are not available.

Food (or 'seston') limitation is thought to be responsible for density-dependent effects in other bivalves (Broom 1982, Peterson 1982, Peterson \& Black 1987, 1988, Peterson \& Beal 1989), and there is some quantitative evidence of seston depletion by intertidal bivalves (e.g. Fréchette \& Bourget 1985, Peterson \& Black 1991). Similarly, benthic bivalves may have a significant impact on phytoplankton biomass in shallow estuaries (Cloern 1982, Nichols 1985, Strayer et al. 1999). This impact is, in some cases, attributed to exotic bivalves such as Potamocorbula amurensis in northern San Francisco Bay (Alpine \& Cloern 1992) and Corbicula fluminea in the Potomac River estuary (Cohen et al. 1984). These studies were all conducted in intertidal areas or in estuaries with mean depths of 2 to $8 \mathrm{~m}$, while our study sites were located in 8 and $15 \mathrm{~m}$ of water.

It is possible that seston depletion also occurs in these deeper waters because seston concentration, in the form of chlorophyll $a$, is relatively low in Port 
Phillip Bay (range of 0.63 to $1.45 \mathrm{\mu g} \mathrm{l}^{-1}$ : Arnott et al. 1997). Similarly, in the 'inner' zone of the bay, where Corbula gibba and Pecten fumatus co-occur, vertical mixing of the water column is weak (Black et al. 1993). If vertical mixing is reduced, replenishment of the benthic boundary layer is decreased and the boundary layer may become depleted of food particles, particularly if the removal rate by suspension feeders is high (Wildish \& Kristmanson 1997).

The surprisingly greater strength of interspecific effects of Corbula gibba on juvenile scallops may be due to faster and/or more efficient filtration by $C$. gibba. Standardised filtration rates (volume per unit time per unit weight) are unavailable, but Kiørboe \& Møhlenberg (1981) found that C. gibba was more efficient at removing food from inhalant water than another scallop species, Aequipecten opercularis. Most of the overlap in the distribution of C. gibba and Pecten fumatus occurs in soft-sediment areas, where above-bottom turbidity is higher than in sandy habitats (e.g. Young \& Rhoads 1971), so an enhanced ability to select organic from inorganic material is an obvious advantage.

Corbula gibba also has adaptations for disposing of large quantities of pseudo-faeces (Yonge 1946), which is another advantage in turbid environments. Part of the negative impact of C. gibba on juvenile scallops may be due to these biodeposits, which can interfere with the feeding and subsequent growth of Pecten fumatus by clogging its feeding mechanisms (Riisgård \& Møhlenberg 1979). The effects of Corbula gibba did not extend to the condition index, and the power to detect a difference in scallop condition between treatments was high, so although scallops were smaller and grew less in the presence of C. gibba, they were not more physiologically 'stressed' than scallops in the control treatment. Rather than depleting energy reserves to maintain growth, scallops with C. gibba grew more slowly.

Similarly, juvenile scallop survival did not differ between treatments and sites, but the power to detect a $50 \%$ decrease in survival was low, so this result needs to be viewed with caution. Other studies that have demonstrated density-dependent growth in bivalves have found survival to be density-independent (Peterson 1982, Peterson \& Black 1987, Heasman et al. 1998). Peterson (1982) suggested that mortality is the last response to competitive stress, following emigration and effects on growth and reproduction. So, although Corbula gibba does not reduce the survival of Pecten fumatus over $2 \mathrm{mo}$, it may do so in the long term or it may increase the susceptibility of scallops to other factors (Peterson \& Black 1988). Only $48 \%$ of juvenile scallops survived the experimental period. This value is very low compared to survival of juveniles protected by mesh in Jervis Bay, New South Wales (Heasman et al. 1998), but similar to estimates for unprotected adult populations in Port Phillip Bay (Gwyther \& McShane 1988). Even though the removable mesh on top of the cages was tied down, small gaps probably allowed access to predators. This high rate of mortality may mean that the survivors who were analysed for their size and growth may have been initially larger or better able to escape predation. C. gibba may therefore have an even greater impact on the less 'fit' juveniles in a population.

The percentage of scallops lost to different sources of mortality did not differ between sites and treatments, despite a larger number of crabs being found in cages at the shallow site. A high percentage was missing from the cages so this source of mortality could not be determined, although it is likely that crab predation was responsible, given that complete shells could not pass through the mesh. Of the crab species found within the cages, Pilumnopeus serratifrons and Litocheira bispinosa would be capable of crushing juvenile scallop shells. Crabs as well as starfish are significant predators of Pecten fumatus elsewhere in Australia (Heasman et al. 1998).

Experimental cages were necessary to maintain treatment densities and to enable retrieval of cryptic juvenile scallops in conditions of poor visibility. However, cages introduce artifacts. For example, the importance of predation as a source of mortality is probably under-estimated, given that cages exclude large predators. Similarly, the cage and its associated fouling community alter water flow, which in turn affects food availability, and the sedimentary and physiocochemical environment within the cage (Hulberg \& Oliver 1980). Peterson \& Beal (1989) found that Mercenaria mercenaria growth was enhanced by up to $21 \%$ inside enclosures, indicating increased food supply. This does not affect the test, as identical cages were used for all treatments, but it is possible that the experiments underestimate the impacts that may occur in more food-limited situations. Cages also prevent emigration, which may be the first response to resource limitation (Peterson 1982). However, even if juveniles were able to move, Corbula gibba is so widespread and abundant, that they may have difficulty finding low-density patches within swimming distance.

Our study provides experimental evidence of resource-restricted growth of bivalves in deep subtidal environments, in contrast to previous work in this area, which has only focussed on bivalves in shallow-water systems. The study is also unique in experimentally demonstrating the impact of an introduced mollusc on an endemic species in Australia, although a better understanding of the impact may be obtained by using a range of natural densities of both species in further 
experiments. Experimental data such as these are important for assessing the true nature of invasion impacts around the world.

Acknowledgements. This paper forms part of a PhD dissertation, which has been funded by the Marine and Freshwater Resources Institute, Fisheries Victoria, and the Faculty of Science, University of Melbourne. Special thanks go to Rod Watson of Queenscliff Marine Station for invaluable assistance in the field, and to the staff of Shellfish Culture Ltd., Tasmania, for supplying the scallops.

\section{LITERATURE CITED}

Alpine AE, Cloern JE (1992) Trophic interactions and direct physical effects control phytoplankton biomass and production in an estuary. Limnol Oceanogr 37:946-955

Arnott GH, Gason AS, Hill DRA, Magro KL, Reilly DJ, Coots AG (1997) Phytoplankton composition, distribution and abundance in Port Phillip Bay from March 1990 to February 1995. Port Phillip Bay Environmental Study Technical Report No. 40

Black KP, Hatton D, Rosenberg M (1993) Locally and externally-driven dynamics of a large semi-enclosed bay in southern Australia. J Coast Res 9:509-538

Bonvicini Pagliai AM, Cognetti Varriale AM, Crema R, Curini Galletti M, Vandini Zunarelli R (1985) Environmental impact of extensive dredging in a coastal marine area. Mar Pollut Bull 16:483-488

Broom MJ (1982) Analysis of the growth of Anadara granosa (Bivalvia: Arcidae) in natural, artificially seeded and experimental populations. Mar Ecol Prog Ser 9:69-79

Carlton JT, Thompson JK, Schemel LE, Nichols FH (1990) Remarkable invasion of San Francisco Bay (California, USA) by the Asian clam Potamocorbula amurensis. I. Introduction and dispersal. Mar Ecol Prog Ser 66:81-94

Christensen AM (1970) Feeding biology of the sea-star Astropecten irregularis Pennant. Ophelia 8:1-134

Cloern JE (1982) Does the benthos control phytoplankton biomass in south San Francisco Bay? Mar Ecol Prog Ser 9: 191-202

Cohen RRH, Dresler PV, Phillips EJP, Cory RL (1984) The effect of the Asiatic clam, Corbicula fluminea on phytoplankton of the Potomac River, Maryland. Limnol Oceanogr 29:170-180

Cohen BF, Currie DR, McArthur MA (2000) Epibenthic community structure in Port Phillip Bay, Victoria, Australia. Mar Freshw Res 51:689-702

Coleman N (1998) Counting scallops and managing the fishery in Port Phillip Bay, south-east Australia. Fish Res (Amst) 38:145-157

Crema R, Castelli A, Prevedelli D (1991) Long term eutrophication effects on macrofaunal communities in northern Adriatic Sea. Mar Pollut Bull 22:503-508

Crooks JA (1998) Habitat alteration and community-level effects of an exotic mussel, Musculista senhousia. Mar Ecol Prog Ser 162:137-152

Currie DR, Parry GD (1996) Effects of scallop dredging on a soft sediment community: a large-scale experimental study. Mar Ecol Prog Ser 134:131-150

Currie DR, Parry GD (1999) Changes to benthic communities over 20 years in Port Phillip Bay, Victoria, Australia. Mar Pollut Bull 38:36-43

Fréchette M, Bourget E (1985) Energy flow between pelagic and benthic zones: factors controlling particulate organic matter available to an intertidal mussel bed. Can J Fish Aquat Sci 42:1158-1165

Griffiths RW, Schloesser DW, Leach JH, Kovalak WP (1991) Distribution and dispersal of the zebra mussel (Dreissena polymorpha) in the Great Lakes region. Can J Fish Aquat Sci 48:1381-1388

Gwyther D, McShane PE (1988) Growth rate and natural mortality of the scallop Pecten alba Tate in Port Phillip Bay, Australia, and evidence for changes in growth rate after a 20-year period. Fish Res 6:347-361

Heasman MP, O'Connor WA, O'Connor SJ, Walker WW (1998) Enhancement and farming of scallops in NSW using hatchery produced seedstock. New South Wales Fisheries, Port Stephens Research Centre, Taylors Beach, NSW (Final Rep Ser Rep No. 8)

Holloway MG (1999) The effects of the introduced fanworm, Sabella spallanzanii, on hard substratum epifaunal assemblages. PhD thesis, University of Melbourne

Hulberg LW, Oliver JS (1980) Caging manipulations in marine soft-bottom communities: importance of animal interactions or sedimentary habitat modifications. Can J Fish Aquat Sci 37:1130-1139

Jensen JN (1990) Increased abundance and growth of the suspension-feeding bivalve Corbula gibba in a shallow part of the eutrophic Limfjord, Denmark. Neth J Sea Res 27:101-108

Kiørboe T, Møhlenberg F (1981) Particle selection in suspension-feeding bivalves. Mar Ecol Prog Ser 5:291-296

Lamprell K, Healy JM, Dyne GR (1998) Superfamily Myoidea. In: Beesley PL, Ross GJB, Wells A (eds) Mollusca: the southern synthesis. CSIRO Publishing, Melbourne, p 363-366

Lucas A, Beninger PG (1985) The use of physiological condition indices in marine bivalve aquaculture. Aquaculture 44:187-200

MacDonald BA, Thompson RJ (1985) Influence of temperature and food availability on the ecological energetics of the giant scallop Placopecten magellanicus. I. Growth rates of shell and somatic tissue. Mar Ecol Prog Ser 25:279-294

Martinez G, Mettifogo L (1998) Mobilization of energy from the adductor muscle for gametogenesis of the scallop, Argopecten purpuratus Lamarck. J Shellfish Res 17: 113-116

Minchin D (1992) Biological observations on young scallops, Pecten maximus. J Mar Biol Assoc UK 72:807-819

Nichols FH (1985) Increased benthic grazing: an alternative explanation for low phytoplankton biomass in northern San Francisco Bay during the 1976-1977 drought. Estuar Coast Shelf Sci 21:379-388

Nichols FH, Thompson JK, Schemel LE (1990) Remarkable invasion of San Francisco Bay (California, USA) by the Asian clam Potamocorbula amurensis. II. Displacement of a former community. Mar Ecol Prog Ser 66:95-101

Ólafsson EB (1986) Density dependence in suspension-feeding and deposit-feeding populations of the bivalve Macoma balthica: a field experiment. J Anim Ecol 55: $517-526$

Peterson CH (1982) The importance of predation and intraand interspecific competition in the population biology of two infaunal suspension-feeding bivalves, Protothaca staminea and Chione undatella. Ecol Monogr 52:437-475

Peterson $\mathrm{CH}$, Beal BF (1989) Bivalve growth and higher order interactions: importance of density, site, and time. Ecology 70:1390-1404

Peterson CH, Black R (1987) Resource depletion by active suspension feeders on tidal flats: influence of local density and tidal elevation. Limnol Oceanogr 32:143-166 
Peterson CH, Black R (1988) Density-dependent mortality caused by physical stress interacting with biotic history. Am Nat 131:257-270

Peterson CH, Black R (1991) Preliminary evidence for progressive sestonic food depletion in incoming tide over a broad tidal sand flat. Estuar Coast Shelf Sci 32:405-413

Pilditch CA, Grant J (1999) Effect of temperature fluctuations and food supply on the growth and metabolism of juvenile sea scallops (Placopecten magellanicus). Mar Biol 134: $235-248$

Race MS (1982) Competitive displacement and predation between introduced and native mud snails. Oecologia 54: 337-347

Riisgård HU, Møhlenberg F (1979) An improved automatic recording apparatus for determining the filtration rate of Mytilus edulis as a function of size and algal concentration. Mar Biol 52:61-67

Ruiz GM, Fofonoff P, Hines AH (1999) Non-indigenous species as stressors in estuarine and marine communities: assessing invasion impacts and interactions. Limnol Oceanogr 44:950-972

Shumway SE, Selvin R, Schick DF (1987) Food resources related to habitat in the scallop Placopecten magellanicus (Gmelin, 1791), a qualitative study. J Shellfish Res 6:89-95

Simberloff DS (1989) Which insect introductions succeed

Editorial responsibility: Otto Kinne (Editor),

Oldendorf/Luhe, Germany and which fail? In: Drake JA, Mooney HA, diCastri F, Groves RH, Kruger FJ, Rejmanek M, Williamson M (eds) Biological invasions: a global perspective. SCOPE 37. John Wiley \& Sons, New York, p 61-75

Sinclair MA (1997) Ecology of intertidal crabs and interaction between native and introduced species of crabs. $\mathrm{PhD}$ thesis, Monash University, Clayton, Victoria

Strayer DL, Caraco NF, Cole JJ, Findlay S, Pace ML (1999) Transformation of freshwater ecosystems by bivalves - a case study of zebra mussels in the Hudson River. BioScience 49:19-27

Talman S (1998) The ecology of an exotic marine bivalve, Corbula gibba, in Port Phillip Bay. Marine and Freshwater Resources Institute, Queenscliff, Victoria (Internal Rep No. 8)

Wildish D, Kristmanson D (1997) Benthic suspension feeders and flow. Cambridge University Press, Cambridge

Wilson RS, Heislers S, Poore GCB (1998) Changes in benthic communities of Port Phillip Bay, Australia, between 1969 and 1995. Mar Freshw Res 49:847-861

Yonge CM (1946) On the habits and adaptations of Aloidis (Corbula) gibba. J Mar Biol Assoc UK 26:358-376

Young DK, Rhoads DC (1971) Animal-sediment relations in Cape Cod Bay, Massachusetts. I. A transect study. Mar Biol 11:242-254

Submitted: January 24, 2000; Accepted: March 1, 2001

Proofs received from author(s): September 24, 2001 